https://doi.org/10.31470/2706-7904-2020-15-241-245

\title{
A THEORETICAL PERSPECTIVE ON PSYCHOLINGUISTICS
}

Теоретичний погляд на психолінгвістику

\author{
Kasım Tatlılıoglu \\ Ph.D. in Psychology, Associate Professor \\ Bingol University, Bingol (Turkey) \\ kasimtatlili@hotmail.com \\ https://orcid.org/0000-0001-5964-4343 \\ Nadiia Senchylo-Tatlılıoglu \\ Ph.D. in Philology \\ National Aviation University (Ukraine) \\ ifyc22@ukr.net \\ https://orcid.org/0000-0001-9196-7118
}

\begin{abstract}
Psycholinguistics or psychology of language is the study of the interrelation between linguistic factors and psychological aspects. Psycholinguistics studies the psychological and neurological factors that enable human to acquire, use and understand language. Psycholinguistics mainly concern with the use of psychological/scientific/experimental methods to study language acquisition, production and processing. In this study is to reveal theoretical information about psycholinguistics.
\end{abstract}

Key words: Linguistics, psycholinguistics, psychology, language, acquisition process.

\section{Introduction}

Psycholinguistics is a science formed with the contributions of linguistics examining the origins, generations and the qualities of language usage, and of psychological science studying the human behaviours. Language acquisition focuses on its comprehension and usage. Psychological processes coming out during the language learning and its usage are analysed in the light of psycholinguistics. This science analyses the relationship between language and exprience, language and mind to search how language is perceived and used from both biological and psychological points of view (Özbay \& Barutçu, 2013: 933). 
Psycholinguistics researchers since the linguistic revolution of the mid - 1960 the field has brooded to encompass a wide range of topics and disciplines. Psycholinguistics is interdisciplinary and is studied in different fields such as psychology, cognitive science and linguistics (Jodai, 2011: 2). Historically the focus of most psycholinguists has been on first language (L1), acquisition of first language in children and in research on adult comprehension and production (Schmitt, 2002).

The relation between language and psychology originates from the fact that an individual forms his/her innate linguistic abilities in compliance with the process of personality development. Chomsky's views that discuss language development within biological and psychological context are referred to as «psycholinguistic» theories (Chomsky, 2000).

\section{Results}

What is psycholinguistics? Psycholinguistics is the branch of cognitive psych ology that studies the psychological basis of linguistic competence and performance. According to Altman (2001) psycholinguistics that $m$ eans psychology of language is the study of the psycho-logical and neurological factors that enable humans to acquire, use, comprehend and produce language. Psycholinguistics or psychology of language is the study of the interrelation between linguistic factors and psychological aspects. Psycholinguistics covers the cognitive processes that make it possible to generate grammatical and meaningful sentences out of vocabulary and grammatical structure as well as the processes that make it possible to understand utterances, words, texts, etc. Psycholinguistics concerns with the study of the cognitive process that supports the acquisition and use of language (Miller \& Emas, 1983; cited in Jodai, 2011: 3).

Who is Psycholinguistics? A psycholinguist is a social scientist who studies psycholinguistics, which connects psychology and linguistics. Psycholinguistics is interdisciplinary in nature and is studied by people in a variety of fields, such as, psychology, cognitive science, linguistics, neuroscience and many more. The main aim of psycholinguistics is to outline and describe the process of producing and comprehending communication.

More specifically, a psycholinguist studies language, speech production, and comprehension by using behavioral and neurological methods traditionally developed in the field of psychology, but other methods such as corpus analysis are also widely used (en.wikipedia.org/wiki/Psycholinguist). Psycholinguists currently represent a widely diverse field. Many psycholinguists are also considered to be neurolinguists, cognitive linguists, neurocognitive linguists, or are associated with those who are (Garnham, 1998). In 
psycholinguistics researchers try to develop models to describe and preferably predict specific linguistic behavior (Gernsbacher, 1994; cited in Jodai, 2011: 8).

The other significance of studying of psycholinguistics is that it uncovers universal processes that governs the development, use and breakdowns of language (Bates et al., 1995; Harley, 2005). Psycholinguistics tries to solve the relationships (the relationship between language and thought) between the individual speaking and the language used by the individual. The main of purpose of psycholinguistics is to outline and describe the process of producing and comprehending communication. In the tradition of psychology, various models are used to further this understanding.

Psycholinguistics as an Interdisciplinary Science. Although linguistics and psychology are different disciplines, the common ground they share is quite vast. The area that covers the act of trying to reach concrete results with reference to scientific data that address the influence of psychology on language and vice versa is referred as the area of interest in psycholinguistics (Taştekin, 2016: 987). Development of the language develops depending on other developmental areas. In this context, psycholinguistics is interdisciplinary (Girgin, 2020: 52). Psycholinguistics is the discipline interested in the common grounds of philology which studies the roots, development and usages of languages and psychology which studies and interprets human behavior. This discipline is interested in how an individual performs the functions of comprehension, interpretation, synthesizing and analyzing as well as the foundations of verbal skills and writing skills. While linguistics deal with one's ability to understand what he/she reads or listens, psycholinguistics interprets this ability by also the emotional effects of it (Taştekin, 2016: 987).

The discipline is mainly concerned with the mechanisms by which language is processed and represented in the mind and brain; that is, the psychological and neurobiological factors that enable humans to acquire, use, comprehend, and produce language (https://en.wikipedia.org/wiki/Psycholinguistics).

Initial forays into psycholinguistics were in the philosophical and educational fields, due mainly to their location in departments other than applied sciences (e.g., cohesive data on how the human brain functioned). Modern research makes use of biology, neuroscience, cognitive science, linguistics, and information science to study how the mind-brain processes language, and less so the known processes of social sciences, human development, communication theories, and infant development, among others. Psycholinguistics contains data that enable not only individuals to express themselves in an elegant and effective way, but also communities to establish a healthy communication. Language education helps individuals find inner peace, feel good and express themselves accurately and perceive their environment accurately as well (Taştekin, 2016: 988). 
The Significance of Psycholinguistic Studies. Psycholinguistics studies the psychological and neurological factors that enable human to acquire, use and understand language. Psycholinguistics mainly concern with the use of psychological / scientific / experimental methods to study language acquisition, production and processing. Language psychology is concerned with the use of language as well as how one performs the function of understanding and comprehension as a listener (Ekmekçi, 1991).

Human being is a thinking and talking creature. Human being differentiates itself from other creatures by being a talking and thinking creature. Human being exports his emotion, thought, experience, knowledge and skill through language. People can use the language to communicate among themselves as long as they exist. It is important to use the language correctly, properly and consistently while communication takes place (Baba, 2020: 95). Educational process supported with the field of psycholinguistics can also decrease the negative effects of the language problems. Language is the medium in which we humans compose our thoughts, explain our thinking, construct our arguments, and create works of literature. Without language, societies as complex as ours could not exist (Pullum, 2018).

\section{Conclusions}

Due to the fact that psycholinguistics is an interdisciplinary field, nowadays it is the focus of researchers who study the interrelation between mind and language. All these visual or auditory modes of communication that are reflected from individual to individual and to the community are related to and in relationship with psycholinguistics. Our emotions shed light on our language, and our choices in language shed light on our emotions. Psycholinguistics authorities are interested in the reflections of the reasons and results of human and animal behavior on language as well as examining the effects of oral, written, visual and behavioral language on human and animal behavior (Taştekin, 2016: 988). Morale and motivation values are in close relation with psycholinguistics. In all visual and auditory arts, language and psychology are prioritized. Because in all forms of art, using language effectively and taking the psychology of target audience into consideration affect the target result positively. Identifying verbal, mathematical and even every kind of artistic intelligence areas in the brain, studies on the function of memory and using NLP (Neuro Linguistic Programming) techniques instead of classic memorization/learning techniques give a different dimension to language learning and language usage. (Taştekin, 2016: 988).

According to (Harely, 2005) the the main subject of research in psycholinguistics is the study of cognitive processes that underlie the comprehension and production of language, and the way the cultural environment interact with these two. Psycholinguistics authorities try to find out methods that are adopted within theories and rules based on rational or scientific data 
through trial, observation and other methods as well as paying attention to subjects that have never been dwelled upon and studied by means of existing methods.

The findings and concepts of psycholinguistics is used and studied by people in a variety of fields. Such as psychology, cognitive science linguistics, and neroulinguistic. There are several subdivisions within psycholinguistics that are based on the components that make up the language (Jodai, 2011: 4). Language development starts from birth and continues throughout life.

\section{References}

Altman, T.M.G. (2001). Psycholinguistics in review. British Journal of Psychology (p. 129-170). Printed in Great Britain the British Psychological Society.

Baba, C. (2020). An assessment of the relationship between Language and Logic. Bartın Universty, Faculty of Islamic Sciences, 40, 95-106.

Bates, E., Dale, P.S., \& Thai, D. (1995) . Individual differences and their implications for theories of language development. In Fletcher \& B. Mac Whinney (Eds.), Handbook of child language (p. 96-115). Oxford: Basil Blackwell.

Chomsky, N. (2000). New horizons in the study of Language and Mind. Cambridge: Cambridge University Press.

Ekmekçi, Ö. (1991). Purpose of psycholinguistics, Çukurova University Journal of Education Faculty, 1, 6-7.

Garnham, A. (1998). Psycholinguistics: Central topics. London, Routledge.

Girgin, İ. (2020). A Review on the language development in early childhood, Journal of Individual Differences in Education, 2(1), 52-63.

Harley, T. (2005). The Psychology of Language. From Data to Theory. New York: Psychology press translation.

Özbay, M. \& Barutçu, T. (2013). Psycholinguistics and Turkish teaching, Adiyaman University. Journal of social sciences, 6(11), 933-973.

Pullum, G.K. (2018). Linguistics: Why it matters. Cambridge.

Schmitt, N. (2002). An introduction to applied linguistics (pp. 133-150). Oxford University press, England.

Taştekin, A. (2016). Areas of interest in psycholinguistics, International Periodical for the Languages, Literature and History of Turkish or Turkic 11(4), 987-1000. https://doi.org/10.7827/TurkishStudies.9075

Jodai, H. (2011). An introduction to psycholinguistics. The University of Guilan, Iran. https://en.wikipedia.org/wiki/Psycholinguistics, Accessed, 12.12.2020

https://www.amazon.com/Linguistics-Matters-Geoffrey-K-Pullum, Accessed, 13.12.2020 